\title{
The Structural Design of Electrode Materials for High Energy Lithium Batteries
}

\author{
Michael THACKERAY \\ Battery Technology Department, \\ Chemical Sciences and Engineering Division, \\ Argonne National Laboratory, Argonne, Illinois 60439, U.S.A.
}

Keywords: Battery, Lithium-Ion, Electrode, Structure, Design, Review

Lithium batteries are used to power a diverse range of applications from small compact devices, such as smart cards and cellular telephones to large heavy duty devices such as uninterrupted power supply units and electric- and hybrid-electric vehicles. This paper briefly reviews the approaches to design advanced materials to replace the lithiated graphite and $\mathrm{LiCoO}_{2}$ electrodes that dominate today's lithiumion batteries in order to increase their energy and safety. The technological advantages of lithium batteries are placed in the context of water-based-and high-temperature battery systems.

\section{Introduction}

The first oil crisis in the mid 1970's spawned intense R\&D efforts to find alternative sources of energy and ways to store energy with the particular objective of lessening the dependence of the world's transportation sector on fossil fuel supplies. Now, more than a generation later, despite the progress that has been made in discovering and developing new battery technologies for energy storage, such as molten salt, high-temperature sodium batteries, aqueous nickelmetal hydride batteries and non-aqueous, room-temperature lithium-ion batteries, further improvements and advances are essential in order to overcome the added concerns of growing $\mathrm{CO}_{2}$ emissions and global warming.

The introduction of primary (non-rechargeable) lithium batteries in the 1970's and, subsequently, secondary (rechargeable) 'lithium-ion' systems in the 1990 's to power portable electronic devices, created a revolution in battery technology and a marked swing away from the relatively low-voltage, water-based systems such as nickel-cadmium and nickel-metal hydride batteries, and high-temperature systems (Linden and Reddy, 2002). Because of their light weight and intrinsic high energy, lithium batteries offer the best opportunity for future progress over all known systems, as highlighted in a volumetric energy density vs. gravimetric energy density plot (Figure 1) and a comparison of theoretical capacities and energy densities of a

Received on May 23, 2007; accepted on June 29, 2007. Correspondence concerning this article should be addressed to M. Thackeray (E-mail address: thackeray@cmt.anl.gov).

Presented at International Symposium on Innovative Materials for Processes in Energy Systems, IMPRES, Kyoto, October, 2007. few selected aqueous, high-temperature (molten salt) and lithium systems (Table 1). Lithium batteries are now being developed for a myriad of devices, both large and small, such as uninterrupted power supply units for the telecommunications industry and those required by the consumer electronics, medical, aerospace, defense and transportation sectors. The lithium battery industry now constitutes a 'lithium economy' that will continue to expand and grow significantly in the years to come, particularly with the introduction of hybrid-electric vehicles (HEVs), 'plug-in' hybridelectric vehicles (PHEVs) and all-electric vehicles (EVs) powered by lithium-ion batteries.

Conventional $4 \mathrm{~V}$ lithium-ion cells, which are based on a $\mathrm{Li}_{x} \mathrm{C}_{6} / \mathrm{Li}_{1-x} \mathrm{CoO}_{2}$ electrochemical couple, provide high energy and power (Linden and Reddy, 2002). In their charged state, they are inherently unsafe. The lithiated-graphite electrode is strongly reducing, whereas a fully delithiated $\mathrm{Li}_{1-x} \mathrm{CoO}_{2}$ electrode is an extremely strong oxidant; in the presence of flammable organic electrolyte solvents, there is the risk of thermal runaway, cell venting, fire and explosion. Therefore, every $\mathrm{Li}_{x} \mathrm{C}_{6} / \mathrm{Li}_{1-x} \mathrm{CoO}_{2}$ cell in a battery pack needs to be protected by electronic circuitry to prevent overcharge. In this respect, much research has been conducted over recent years to find alternative electrode materials in the quest for safer lithium-ion batteries.

Although lithiated graphite remains the material of choice for the negative electrode (anode), considerable progress is being made to fabricate practical metal alloy or intermetallic electrodes that can store greater amounts of lithium. With respect to the positive electrode (cathode), the spinel $\mathrm{LiMn}_{2} \mathrm{O}_{4}$ (Thackeray et al., 1984a; Ohzuku et al., 1990) and its substituted derivatives (Gummow et al., 1994), and $\mathrm{LiFePO}_{4}$ (olivine) 
Table 1 Selected battery systems and their theoretical electrochemical properties (based on the masses of active electrode and electrolyte components only)

\begin{tabular}{|c|c|c|c|c|c|}
\hline $\begin{array}{c}\text { System } \\
\text { Lead - acid }\end{array}$ & $\begin{array}{c}\text { Negative } \\
\text { electrode }\end{array}$ & $\begin{array}{c}\text { Positive } \\
\text { electrode }\end{array}$ & $\begin{array}{c}\text { OcV } \\
(\mathrm{V})\end{array}$ & $\begin{array}{c}\text { Th. Cap } \\
(\mathrm{Ah} / \mathrm{kg})\end{array}$ & $\begin{array}{c}\text { Th En. } \\
(\mathrm{Wh} / \mathrm{kg})\end{array}$ \\
\hline $\mathrm{Ni}-\mathrm{Cd}$ & $\mathrm{Cd}$ & $\mathrm{NiOOH}$ & 1.35 & 162 & 219 \\
\hline $\mathrm{Ni}-\mathrm{MH}$ & $\mathrm{MH}$ alloy & $\mathrm{NiOOH}$ & 1.35 & $\sim 178$ & $\sim 240$ \\
\hline $\mathrm{Na}-\mathrm{S}\left(350^{\circ} \mathrm{C}\right)$ & $\mathrm{Na}$ & $\mathrm{S}$ & $2.1-1.78(2.0)$ & 377 & $\sim 754$ \\
\hline $\mathrm{Na}-\mathrm{MCl}_{2}\left(300^{\circ} \mathrm{C}\right)$ & $\mathrm{Na}$ & $\mathrm{NiCl}_{2}$ & 2.58 & 305 & 787 \\
\hline $\mathrm{Li}-\mathrm{lon}$ & $\mathrm{Li}_{\mathrm{x}} \mathrm{C}_{6}$ & $\mathrm{Li}_{1-\mathrm{x}} \mathrm{CoO}_{2}$ & $4.2-3.0(\sim 3.8)$ & $158(\mathrm{x}=1.0)$ & $\sim 600$ \\
\hline $\mathrm{Li}-$ polymer & $\mathrm{Li}$ & $\mathrm{Li}_{1+\mathrm{x}} \mathrm{V}_{3} \mathrm{O}_{8}$ & $\sim 3.3-2.0(\sim 2.6)$ & $\sim 340(\mathrm{x}=4)$ & $\sim 884$ \\
\hline $\mathrm{Li}-\mathrm{S}$ & $\mathrm{Li}$ & $\mathrm{S}$ & $>2$ & 1169 & $>2338$ \\
\hline
\end{tabular}

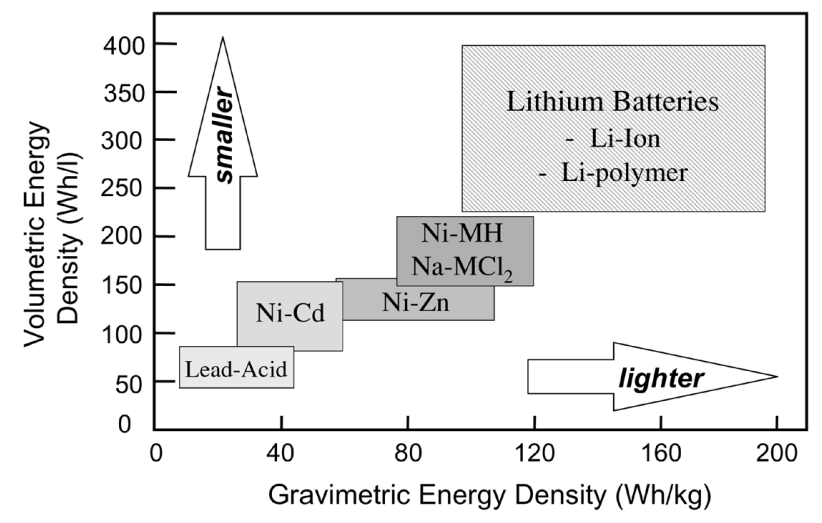

Fig. 1 Energy density plots of various batteries

(Padhi et al., 1997) have also been commercialized in high-voltage lithium-ion cells. In practice, however, all three materials $\left(\mathrm{LiCoO}_{2}, \mathrm{LiMn}_{2} \mathrm{O}_{4}\right.$ and $\left.\mathrm{LiFePO}_{4}\right)$ provide a relatively low electrochemical capacity at high potentials $(3.5-4 \mathrm{~V})$, thereby limiting the available energy of the lithium-ion cell. Recently, it has been demonstrated that lithium-rich, $\mathrm{Li}_{2} \mathrm{MnO}_{3}$-stabilized $\mathrm{Li}_{1+x} \mathrm{M}_{1-x} \mathrm{O}_{2}$ electrodes in which $\mathrm{M}$ is predominantly manganese and nickel hold promise for increasing the capacity and energy of lithium-ion cells (Lu et al., 2002; Kim et al., 2004; Thackeray et al., 2005).

In this paper, the progress that has been made in developing alternative lithium battery materials is briefly reviewed; the importance of designing rechargeable electrodes from both a compositional and structural standpoint is highlighted. Technological advances and future opportunities are discussed in relation to other battery systems.

\section{Insertion vs. Displacement Reactions}

Electrochemical reactions take place, in general, either by insertion reactions or displacement reactions or a combination thereof. Insertion reactions occur when a guest ion, such as $\mathrm{H}^{+}$or $\mathrm{Li}^{+}$, is accommodated within a host electrode structure. Well known examples of reversible insertion reactions are found in nickel-metal hydride- and lithium-ion batteries in which the $\mathrm{H}^{+}$and $\mathrm{Li}^{+}$ions are shuttled between the host structures of the metal $(\mathrm{M})$ and graphite $\left(\mathrm{C}_{6}\right)$ anodes and the $\mathrm{NiOOH}$ and $\mathrm{Li}_{1-x} \mathrm{CoO}_{2}$ cathodes, according to reactions (1) and (2), respectively (Linden and Reddy, 2002):

$$
\begin{aligned}
& \mathrm{MH}+\mathrm{NiOOH} \leftrightarrow \mathrm{M}+\mathrm{Ni}(\mathrm{OH})_{2} \\
& \mathrm{Li}_{x} \mathrm{C}_{6}+\mathrm{Li}_{1-x} \mathrm{CoO}_{2} \leftrightarrow \mathrm{C}_{6}+\mathrm{LiCoO}_{2}
\end{aligned}
$$

The theoretical capacity of each electrode is determined by the number of electrons transferred during the electrochemical reaction. For reactions (1) and (2) above, a maximum of one electron can be transferred per transition metal ion in the $\mathrm{NiOOH}$ and $\mathrm{Li}_{1-x} \mathrm{CoO}_{2}$ $(0 \leq x \leq 1)$ electrodes. For delithiated $\mathrm{Li}_{1-x} \mathrm{CoO}_{2}$ electrodes, however, $x_{\max }$ is limited in practice to approximately 0.5 because the structure becomes unstable at higher values of $x$.

Reversible displacement reactions, sometimes referred to as 'conversion' reactions, in which new phases are constructed during discharge and charge, can occur by multi-electron transfer processes, as exemplified by the reactions of lead-acid- and high-temperature sodium-nickel chloride batteries that allow for the transfer of 2 electrons per $\mathrm{Pb}$ and $\mathrm{Ni}$ redox centers, respectively, as shown in reactions (3) and (4) (Sudworth, 2001; Linden and Reddy, 2002):

$$
\begin{aligned}
& \mathrm{Pb}+\mathrm{PbO}_{2}+\mathrm{H}_{2} \mathrm{SO}_{4} \leftrightarrow 2 \mathrm{PbSO}_{4}+\mathrm{H}_{2} \mathrm{O} \\
& 2 \mathrm{Na}+\mathrm{NiCl}_{2} \leftrightarrow 2 \mathrm{NaCl}+\mathrm{Ni}
\end{aligned}
$$


High-temperature Li/iron-oxide $\left(\mathrm{Fe}_{3} \mathrm{O}_{4}\right.$, spinel) cells operate by combined lithium insertion/metal displacement reaction processes in the cathode that involve 2.33 electrons per iron atom (Thackeray et al., 1981). The overall reaction that occurs between $2.0-1.0 \mathrm{~V}$, is simply:

$$
8 \mathrm{Li}+\mathrm{Fe}_{3} \mathrm{O}_{4} \leftrightarrow 4 \mathrm{Li}_{2} \mathrm{O}+8 \mathrm{Fe}
$$

During discharge, lithium is inserted into, and iron extruded from, a fixed cubic-close-packed (ccp) oxygen array that acts as the host framework for both lithium and iron (Thackeray et al., 1984b); intermediate ccp $\mathrm{LiFe}_{5} \mathrm{O}_{8}, \mathrm{LiFeO}_{2}$ and $\mathrm{Li}_{5} \mathrm{FeO}_{4}$ phases are generated prior to the final $\mathrm{Li}_{2} \mathrm{O}$ and $\mathrm{Fe}$ reaction products. The reaction is reversible; during charge, iron is reaccommodated within the ccp oxygen array and lithium is deposited at the anode. A similar lithium insertion/ copper displacement reaction has been reported for $\mathrm{Cu}_{2.33} \mathrm{~V}_{4} \mathrm{O}_{11}$ (Morcrette et al., 2003). Although such lithium insertion/metal displacement reactions occur at lower potentials than lithium insertion/extraction reactions with $\mathrm{LiCoO}_{2}, \mathrm{LiMn}_{2} \mathrm{O}_{4}$ and $\mathrm{LiFePO}_{4}$, they offer, in principle, the possibility of increasing the cathode capacity and hence the energy delivered by lithium cells and batteries.

\section{Required Properties of Li Insertion Electrodes}

Lithium-ion cells operate by lithium insertion/extraction reactions that can be represented, in general, as:

$$
\mathrm{Li}_{x} \mathrm{H}_{\mathrm{a}}+\mathrm{H}_{\mathrm{c}} \leftrightarrow \mathrm{H}_{\mathrm{a}}+\mathrm{Li}_{x} \mathrm{H}_{\mathrm{c}}
$$

where $\mathrm{H}_{\mathrm{a}}$ and $\mathrm{H}_{\mathrm{c}}$ are the host anode and host cathode materials, such as graphite $\left(\mathrm{C}_{6}\right)$ and a transition metal oxide, respectively. Ideally, lithium insertion electrodes should have the following intrinsic properties:

- The host electrodes, $\mathrm{H}_{\mathrm{a}}$ and $\mathrm{H}_{\mathrm{c}}$, should accept and release as much lithium $(x)$ as possible to provide a cell with high capacity and energy.

- The host electrodes should be stable over a wide compositional range $(x)$ to ensure a good cycle life. In this respect, there should be minimal change to the unit cell parameters and volume of the host structures; the expansion/contraction of the unit cell should be isotropic rather than anisotropic.

- $\quad \mathrm{H}_{\mathrm{a}}$ should have a low electrochemical potential vs. metallic lithium, whereas $H_{c}$ should have a high potential vs. lithium so that the cell has a high voltage.

- The structures of $\mathrm{H}_{\mathrm{a}}$ and $\mathrm{H}_{\mathrm{c}}$ should have an energetically-favorable interstitial space to allow fast $\mathrm{Li}^{+}$-ion transport and they should be good electronic conductors to ensure high power.
The mineral world provides numerous examples of stable compounds that are produced under a variety of conditions, such as high temperature, high pressure, from solution and by ion-exchange. Mineral structures can, therefore, be used as a guide to identify and select stable insertion electrodes. It is perhaps not surprising that the three major cathode materials used in commercial lithium-ion cells have well known mineral structures, namely $\mathrm{LiCoO}_{2}$ (rocksalt), $\mathrm{LiMn}_{2} \mathrm{O}_{4}$ (spinel) and $\mathrm{LiFePO}_{4}$ (olivine) of which only $\mathrm{LiFePO}_{4}$ is found in nature in its fully discharged state (triphylite) and in its fully delithiated state, $\mathrm{FePO}_{4}$ (heterosite), although both triphylite and heterosite commonly contain $\mathrm{Mn}$ impurities. Synthetic $\mathrm{LiFePO}_{4}$ electrodes are extremely stable to the repeated insertion and extraction of lithium.

A major advantage of lithium-ion battery technology is that it is extremely versatile. The potential of the host electrodes and, therefore, the cell voltage can be tailored by the selection of (1) the structure type of the insertion electrode and (2) the electrochemically active redox centers. Consequently, lithium-ion cells can be designed with voltages between 1 and $5 \mathrm{~V}$. By contrast, the voltage of most other battery systems is defined narrowly by their more specific cell chemistries, as in lead-acid, nickel-cadmium, nickel-metal hydride and sodium-nickel chloride batteries.

\section{Cathode Materials}

\subsection{Limitations of existing electrode materials for lithium-ion systems}

Schematic illustrations of the three commercially exploited lithium battery cathode structures, namely layered $\mathrm{LiMO}_{2}(\mathrm{M}=\mathrm{Co}, \mathrm{Ni}, \mathrm{Mn})$, spinel $\mathrm{LiMn}_{2} \mathrm{O}_{4}$ and olivine $\mathrm{LiFePO}_{4}$ are shown in Figures $2(\mathbf{a})-(\mathbf{c})$, respectively. Despite their commercial use, the electrochemical properties of these electrodes are constrained in various ways by certain intrinsic limitations. 3.1.1 Layered LiMO $_{2}$ electrodes $\quad$ When $\mathrm{M}=\mathrm{Co}$ and/or $\mathrm{Ni}$, the practical capacity of $\mathrm{LiMO}_{2}$ electrodes is limited by the extent to which lithium can extracted from, and reinserted into the $\mathrm{Li}_{1-x} \mathrm{MO}_{2}$ electrode structure. In practice, $x$ is limited to $\sim 0.5$, which corresponds to an electrochemical capacity of $\sim 140 \mathrm{~mA} \cdot \mathrm{h} / \mathrm{g}$ (Mizushima et al., 1980). The delithiated structures are unstable at lower lithium content because of the high electrochemical potential ( 4 V vs. $\left.\mathrm{Li}^{0}\right)$ and high reactivity of the tetravalent $\mathrm{Co}^{4+}$ and $\mathrm{Ni}^{4+}$ ions, particularly with respect to the electrolyte. When $\mathrm{M}=\mathrm{Mn}$, the delithiated layered $\mathrm{Li}_{1-x} \mathrm{MnO}_{2}$ electrode is stabilized by a structural transformation to spinel, which lowers its average operating potential; the spinel-related electrode delivers most of its capacity below $3 \mathrm{~V} \mathrm{vs.} \mathrm{Li}^{0}$.

$\underline{\text { 3.1.2 Spinel LiMn }} 2 \underline{\mathrm{O}}_{4}$ electrodes $\quad \mathrm{A} \mathrm{Li}_{x} \mathrm{Mn}_{2} \mathrm{O}_{4}$ spinel electrode delivers one-half of its capacity at $\sim 4 \mathrm{~V}$ over the compositional range $0 \leq x<1$ (Ohzuku 


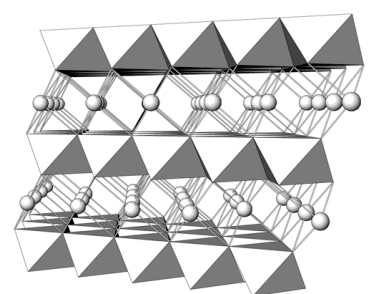

(a)

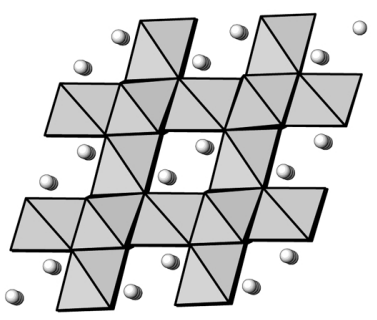

(b)

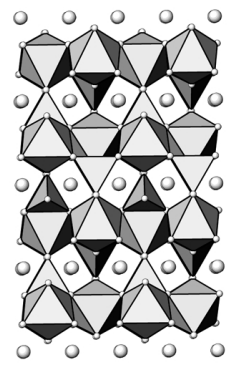

(c)

Fig. 2 Schematic illustrations of the structures of (a) $\mathrm{LiMO}_{2}(\mathrm{M}=\mathrm{Co}, \mathrm{Ni}, \mathrm{Mn}) ;$ (b) $\mathrm{LiMn}_{2} \mathrm{O}_{4} ;(\mathrm{c}) \mathrm{LiFePO}_{4}$. Lithium ions are shown as dots; the remaining cations reside within shaded $\mathrm{O}$ polyhedra

et al., 1990; Thackeray et al., 1997), and the other half at $\sim 3 \mathrm{~V}$ for $1 \leq x \leq 2$ (Thackeray et al., 1983). Because there are two manganese ions per spinel formula unit, the $4-\mathrm{V}$ capacity is restricted to $0.5 \mathrm{Li}$ per transition metal ion, like the layered $\mathrm{LiMO}_{2}$ electrodes $(\mathrm{M}=\mathrm{Co}$, $\mathrm{Ni}$ ) mentioned above in practical cells; the theoretical $4 \mathrm{~V}$ capacity of $\mathrm{LiMn}_{2} \mathrm{O}_{4}$ is $148 \mathrm{~mA} \cdot \mathrm{h} / \mathrm{g}$, most of which can be realized in practice. Discharge at $3 \mathrm{~V}$ is compromised by a severe crystallographic (Jahn-Teller) distortion as a result of the high concentration of $\mathrm{Mn}^{3+}$ in the electrode, which damages its cycling efficiency. Furthermore, $\mathrm{LiMn}_{2} \mathrm{O}_{4}$ spinel electrodes are prone to dissolution in the slightly acidic electrolytes of lithiumion cells, which damages cycling stability, particularly at elevated temperature $\left(\sim 50^{\circ} \mathrm{C}\right)$. Nevertheless, despite these disadvantages, progress has been made to stabilize the spinel structure to counter these effects, notably by substituting a small amount of manganese in the spinel framework by lithium $\left(\mathrm{Li}_{1+x} \mathrm{Mn}_{2-x} \mathrm{O}_{4}\right)$, thereby raising the average oxidation state of the $\mathrm{Mn}$ ions above 3.5 (Gummow et al., 1994). The robust $\left[\mathrm{Mn}_{2-\delta} \mathrm{Li}_{\delta}\right] \mathrm{O}_{4}$ spinel framework with its three-dimensional interstitial space for lithium diffusion allows the spinel electrode to operate at extremely high rates.

3.1.3 Olivine $\mathrm{LiFePO}_{4}$ electrodes $\quad$ The olivine structure is the hexagonally-close-packed equivalent of the ccp spinel structure; both structure types can be represented in $\mathrm{AB}_{2} \mathrm{O}_{4}$ notation where $\mathrm{A}$ refers to cations in tetrahedral sites and $\mathrm{B}$ to cations in octahedral sites. Although all the lithium can be extracted from LiFePO ${ }_{4}$, i.e., $1 \mathrm{Li}$ per transition metal ion $(\mathrm{Fe})$, the theoretical capacity of the electrode $(175 \mathrm{~mA} \cdot \mathrm{h} / \mathrm{g})$ is only slightly greater than that offered by $\mathrm{LiMn}_{2} \mathrm{O}_{4}$ (148 $\mathrm{mA} \cdot \mathrm{h} / \mathrm{g}$ ) because $\mathrm{LiFePO}_{4}$ also contains electrochemically inactive $\mathrm{P}$ cations (Padhi et al., 1997). The excellent stability of $\mathrm{LiFePO}_{4}$ to repeated lithium extraction and reinsertion and the ability to use stable nanosized particles, connected to one another by an electronically-conducting species such as carbon, helps to offset the intrinsically low ionic and electronic conductivity of $\mathrm{LiFePO}_{4}$ electrodes (Ravet et al.,
2001). However, electrodes comprised of nano-sized particles tend to have a low packing ('tap') density which compromises the volumetric energy density of the cells.

The greatest limitation of all three cathode materials mentioned above is capacity. New approaches to design alternative materials are clearly required if lithium-ion batteries are to meet the demands of highenergy applications, such as plug-in hybrid vehicles, that will be dependent on batteries with sufficient energy and power to sustain the vehicle over longer distances than is currently possible.

\subsection{Design of composite electrode structures}

Recent advances have been made in improving the capacity and stability of layered $\mathrm{LiMO}_{2}$ and spinel $\mathrm{LiM}_{2} \mathrm{O}_{4}$ electrodes by integrating a structurally compatible component, such as $\mathrm{Li}_{2} \mathrm{TiO}_{3}$ (Kim et al., 2002) or $\mathrm{Li}_{2} \mathrm{MnO}_{3}$ (Johnson et al., 2005; Thackeray et al., 2005), into the close-packed parent structure. The approach follows the rationale of using two-component structures to design materials with significantly improved electrochemical properties. For example, in the family of solid electrolytes, it is well known that structures with anomalously high Ag+-ion conductivity at room temperature can be fabricated by reacting $\mathrm{AgI}$ with other iodide salts such as RbI and $\mathrm{C}_{11} \mathrm{H}_{30} \mathrm{~N}_{3} \mathrm{I}_{3}$ to yield, respectively, $\mathrm{RbAg}_{4} \mathrm{I}_{5}$ (RbI.4AgI) (Hull et al., 2002) and $\mathrm{Ag}_{44} \mathrm{I}_{53}\left(\mathrm{C}_{11} \mathrm{H}_{30} \mathrm{~N}_{3} \mathrm{I}_{3}\right)_{3}\left(44 \mathrm{AgI} \cdot 3 \mathrm{C}_{11} \mathrm{H}_{30} \mathrm{~N}_{3} \mathrm{I}_{3}\right)$ (Thackeray et al., 1978). It is also now commonly known that $\mathrm{Li}_{2} \mathrm{O}$ units can stabilize a wide range of $\mathrm{MnO}_{2}$ electrode structures such as gamma- $\mathrm{MnO}_{2}$ and $\alpha-\mathrm{MnO}_{2}$, resulting in $\mathrm{Li}_{2} \mathrm{O} \cdot y \mathrm{MnO}_{2}$ products with superior electrochemical properties compared to the parent $\mathrm{MnO}_{2}$ materials (Thackeray et al., 1993, 1997; Johnson et al., 1997).

Of particular significance are the advantages that $\mathrm{Li}_{2} \mathrm{MnO}_{3} \cdot \mathrm{LiMO}_{2}(\mathrm{M}=\mathrm{Mn}, \mathrm{Ni}, \mathrm{Co})$ composite electrode structures offer over conventional layered $\mathrm{LiMO}_{2}$ materials, such as $\mathrm{LiCoO}_{2}, \mathrm{LiNiO}_{2}, \mathrm{LiMnO}_{2}$, and combinations thereof (Thackeray et al., 2007). The structures are extremely complex; they are characterized by cation 


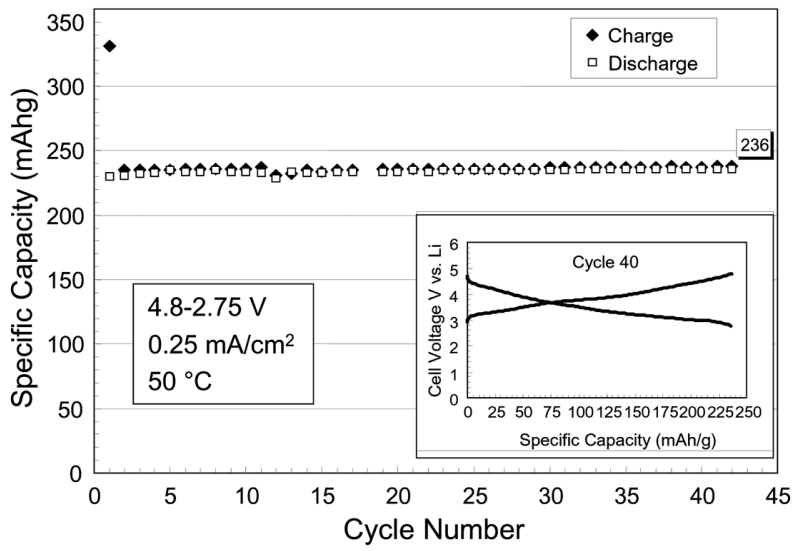

Fig. 3 Electrochemical cycling behavior of a lithium cell with a $0.3 \mathrm{Li}_{2} \mathrm{MnO}_{3} \cdot 0.7 \mathrm{LiMn}_{0.5} \mathrm{Ni}_{0.5} \mathrm{O}_{2}$ composite cathode structure between 4.8 and $2.75 \mathrm{~V}$ at $50^{\circ} \mathrm{C}$. Figure reproduced from Johnson et al. (2007) with permission from Elsevier

disorder between the highly integrated $\mathrm{Li}_{2} \mathrm{MnO}_{3}$ - and $\mathrm{LiMO}_{2}$ components. The $\mathrm{Li}_{2} \mathrm{MnO}_{3}$ component serves a vital role in stabilizing the $\mathrm{LiMO}_{2}$ component and influencing the electrochemical properties of the electrode. For example, it is possible to activate the $\mathrm{Li}_{2} \mathrm{MnO}_{3}$ component by extracting $\mathrm{Li}_{2} \mathrm{O}$ at high potentials, typically $>4.5 \mathrm{~V}$, to form a $\mathrm{MnO}_{2}$ component within the charged electrode structure and, in so doing, to tailor and optimize compositional, structural and electrochemical properties (Johnson et al., 2004). It is, however, important to maintain some unactivated $\mathrm{Li}_{2} \mathrm{MnO}_{3}$ in the composite $\mathrm{Li}_{2} \mathrm{MnO}_{3} \cdot \mathrm{LiMO}_{2}$ structure because it acts as a reservoir for excess lithium that can diffuse during the charging process from the transitional metal layers into adjacent lithium-depleted layers to stabilize the electrode structure (Grey et al., $2004)$, thereby allowing high practical capacities ( $>200$ $\mathrm{mA} \cdot \mathrm{h} / \mathrm{g}$ ) to be delivered reversibly on charge and discharge. Moreover, the $\mathrm{Li}_{2} \mathrm{MnO}_{3}$ component serves not only as a stabilizing agent, but it also contributes as an electrolyte to facilitate $\mathrm{Li}^{+}$-ion transport between the electrochemically active regions of the electrode structure.

The excellent electrochemical cycling behavior of a $\mathrm{Li} / 0.3 \mathrm{Li}_{2} \mathrm{MnO}_{3} \cdot 0.7 \mathrm{LiMn}_{0.5} \mathrm{Ni}_{0.5} \mathrm{O}_{2}$ cell is shown in Figure 3, in which the typical voltage profile (40th cycle) is provided as an inset (Johnson et al., 2007). After the initial charge-discharge 'formation' cycle, the $0.3 \mathrm{Li}_{2} \mathrm{MnO}_{3} \cdot 0.7 \mathrm{LiMn}_{0.5} \mathrm{Ni}_{0.5} \mathrm{O}_{2}$ electrode provides an impressive, reversible capacity of approximately $230 \mathrm{~mA} \cdot \mathrm{h} / \mathrm{g}$ between 4.8 and $2.75 \mathrm{~V}$ at a $0.25 \mathrm{~mA} / \mathrm{cm}^{2}$ rate, which is $64 \%$ greater than the typical practical capacity delivered by a standard $\mathrm{LiCO}_{2}$ electrode $(\sim 140 \mathrm{~mA} \cdot \mathrm{h} / \mathrm{g})$.

Calorimetric studies have shown that $\mathrm{Li}_{2} \mathrm{MnO}_{3} \cdot \mathrm{LiMO}_{2}$ composite electrode structures gen- (a)

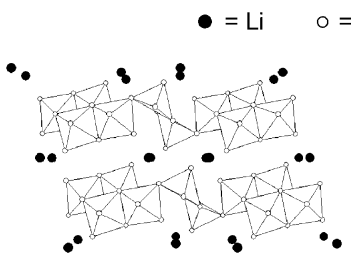

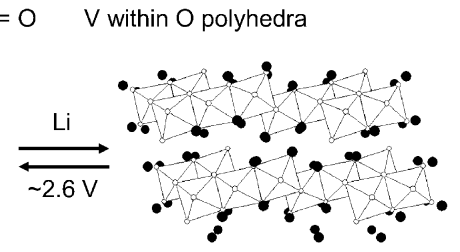

(b)
Fig. 4 The anisotropic crystallographic transformation of $\mathrm{LiV}_{3} \mathrm{O}_{8}$ to $\mathrm{Li}_{4} \mathrm{~V}_{3} \mathrm{O}_{8}$ that occurs without volume change

erate less heat than conventional $\mathrm{LiMO}_{2}$ electrodes $(\mathrm{M}=\mathrm{Co}, \mathrm{Ni})$ when reacted with the electrolyte in their charged state; they exhibit a higher onset temperature, rendering them less prone to thermal runaway ( $\mathrm{Lu}$ et al., 2006).

\subsection{Cathodes for solid state lithium-polymer bat- teries}

Despite the problems and safety limitations of using metallic lithium as an anode in lithium batteries, considerable success has been obtained in engineering all-solid-state $\mathrm{Li} /$ polymer electrolyte/metal oxide cells and batteries. The polyethyleneoxide-based solid polymer electrolyte suppresses lithium dendrite formation and the moss-like, high surface area- and highly reactive lithium that can be generated when liquid electrolyte lithium cells are cycled. Solid state lithiumpolymer batteries are currently being manufactured for uninterrupted-power-supply (UPS) units; they are well suited for this purpose because UPS batteries are not often subjected to continuous charge/discharge cycling. The metal oxide cathode of choice for lithium-polymer cells is $\mathrm{LiV}_{3} \mathrm{O}_{8}$, the structure of which and that of its lithiated product, $\mathrm{Li}_{4} \mathrm{~V}_{3} \mathrm{O}_{8}$, are shown in Figure 4.

Both $\mathrm{LiV}_{3} \mathrm{O}_{8}$ and $\mathrm{Li}_{4} \mathrm{~V}_{3} \mathrm{O}_{8}$ have monoclinic symmetry, $\mathrm{P} 21 / \mathrm{m}$. The lattice constants of $\mathrm{LiV}_{3} \mathrm{O}_{8}$, namely, $a=6.595 \AA ; b=3.559 \AA ; c=11.862 \AA, \beta=107.66^{\circ}$ change anisotropically on lithiation to $\mathrm{Li}_{4} \mathrm{~V}_{3} \mathrm{O}_{8}$, for which the corresponding parameters are $a=5.955 \AA$; $b=3.911 \AA ; c=11.915 \AA, \beta=107.03^{\circ}$ (de Picciotto et $a l ., 1993 \mathrm{a})$. Although $a$ and $b$ contract and expand markedly during the lithiation process, there is no significant change to the unit cell volume (265.36 and $265.33 \AA^{3}$, respectively). Despite the minimal change in unit cell volume, the anisotropic variation of the lattice parameters can cause severe cracking and loss of contact between electrode particles as illustrated by the image of lithiated $\mathrm{Li}_{4} \mathrm{~V}_{3} \mathrm{O}_{8}$ crystals obtained by reacting $\mathrm{LiV}_{3} \mathrm{O}_{8}$ with $n$-butyllithium at room temperature (Figure 5) (de Picciotto et al., 1993b).

Such damaging crystallographic phenomena must be countered by careful attention to binders and electronically conductive additives to ensure that electronic contact between the electrochemically-active electrode 


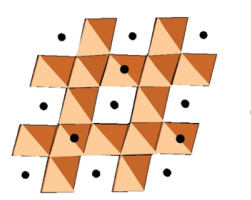

$\mathrm{Li}_{7} \mathrm{Ti}_{5} \mathrm{O}_{12}$ (a)

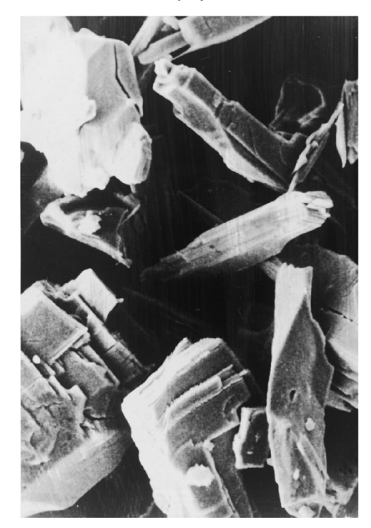

Fig. $5 \mathrm{LiV}_{3} \mathrm{O}_{8}$ crystals (a) before and (b) after lithiation with $n$-butyllithium at room temperature

particles is maintained at all times during charge and discharge to guarantee an acceptable cycle life. The theoretical capacity of a $\mathrm{LiV}_{3} \mathrm{O}_{8}$ electrode for lithiation to $\mathrm{Li}_{4} \mathrm{~V}_{3} \mathrm{O}_{8}$ is $280 \mathrm{~mA} \cdot \mathrm{h} / \mathrm{g}$, almost all of which can be obtained in practice in lithium polymer cells at an average voltage of $2.5 \mathrm{~V}$ at slow current rates (West et al. 1996).

\section{Anode Materials}

\subsection{Graphite}

Graphite remains the anode material of choice for lithium-ion cells. Charged, lithiated graphite $\left(\mathrm{LiC}_{6}\right)$ electrodes operate at a potential just above that of metallic lithium (Dahn et al., 1995). Although the containment of lithium within the graphite sheets, and the protecting solid-electrolyte-interphase (SEI) layer that forms between the lithiated graphite particles and the electrolyte alleviate the problems of dendrite formation, there are still concerns about the high reactivity and safety of $\mathrm{LiC}_{6}$ electrodes, particularly with respect to the flammable electrolyte solvents used in lithiumion cells. For this reason, a concerted effort is being made by the international lithium battery community to find alternative anode materials that operate above the potential of lithiated graphite, such as lithiated metal oxides, metals, semimetals and intermetallic

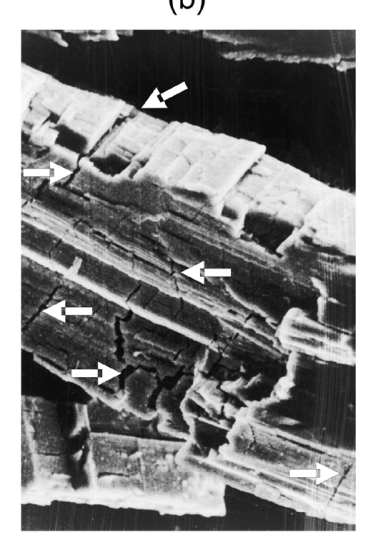

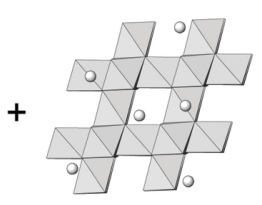

$\mathrm{Li}_{1+x-y} \mathrm{Mn}_{2-\mathrm{x}} \mathrm{O}_{4}$

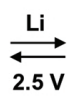

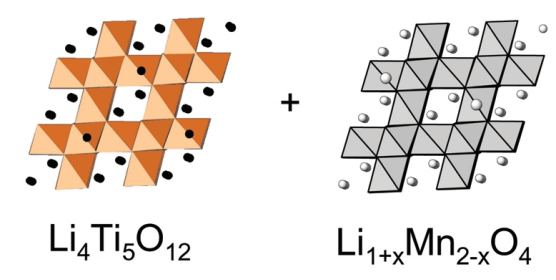

Fig. 6 Schematic illustration of a $\mathrm{Li}_{4} \mathrm{Ti}_{5} \mathrm{O}_{12} / \mathrm{Li}_{1+x} \mathrm{Mn}_{2-x} \mathrm{O}_{4}$ 'spinel-spinel' lithium-ion cell

compounds.

\subsection{Metal oxides}

Metal oxide insertion electrodes are attractive alternatives to graphite because they react, in general, with lithium at potentials sufficiently far from the lithium potential. However, increasing the anode potential and improving the safety of a lithium-ion cell compromises the cell voltage, and hence the energy of the cell. For example, titanium oxide insertion electrodes such as $\mathrm{Li}_{4} \mathrm{Ti}_{5} \mathrm{O}_{12}$ (Colbow et al., 1989), $\mathrm{TiO}_{2}$ nanotubes and nanowires (Armstrong et al., 2004, 2006), and $\mathrm{Li}_{2} \mathrm{MTi}_{6} \mathrm{O}_{14}(\mathrm{M}=\mathrm{Ba}, \mathrm{Sr})$ (Belharouak and Amine, 2003) that operate at approximately $1.5 \mathrm{~V}$ above the potential of metallic lithium, provide safe electrochemical couples when paired with $\mathrm{LiCoO}_{2}$, $\mathrm{LiMn}_{2} \mathrm{O}_{4}$ and $\mathrm{LiFePO}_{4}$ cathodes. The net voltage of these cells falls within the approximate range 2.5$2.0 \mathrm{~V}$. The best known titanate anode is the spinel $\mathrm{Li}_{4} \mathrm{Ti}_{5} \mathrm{O}_{12}$, that can be reformulated in spinel notation as $\mathrm{Li}\left[\mathrm{Li}_{1 / 3} \mathrm{Ti}_{5 / 3}\right] \mathrm{O}_{4} . \mathrm{Li}_{4} \mathrm{Ti}_{5} \mathrm{O}_{12}$ is an extremely stable compound; it can be prepared and used in nano-particulate form. The robust $\left[\mathrm{Li}_{1 / 3} \mathrm{Ti}_{5 / 3}\right] \mathrm{O}_{4}$ spinel framework, like the $\left[\mathrm{Mn}_{2}\right] \mathrm{O}_{4}$ spinel framework of $\mathrm{Li}\left[\mathrm{Mn}_{2}\right] \mathrm{O}_{4}$, provides a three-dimensional space for rapid lithium-ion transport. A 2.5-V spinel-spinel couple comprising a $\mathrm{Li}_{4} \mathrm{Ti}_{5} \mathrm{O}_{12}$ anode and lithium-stabilized $\mathrm{Li}_{1+x} \mathrm{Mn}_{2-x} \mathrm{O}_{4}$ couple was advocated several years ago as a safe electrochemical couple (Ferg et al., 1994). During charge and discharge, lithium is simply transferred between two cubic host spinel structures (Figure 6); during these reactions, there is essentially no volume expansion or contraction of the $\left[\mathrm{Li}_{1 / 3} \mathrm{Ti}_{5 / 3}\right] \mathrm{O}_{4}$ spinel framework, whereas the $\left[\mathrm{Li}_{x} \mathrm{Mn}_{2-x}\right] \mathrm{O}_{4}$ framework expands and contracts isotropically by only $\sim 5 \%$. Highrate $\mathrm{Li}_{4} \mathrm{Ti}_{5} \mathrm{O}_{12}-\mathrm{Li}_{1+x} \mathrm{Mn}_{2-x} \mathrm{O}_{4}$ lithium-ion batteries are currently receiving considerable interest for hybrid electric vehicles, in which the battery is used predominantly as a 'power assist' to improve the fuel efficiency of the vehicle.

Fairly recently, nanoparticulate metal oxides such as $\mathrm{CoO}$ that operate by reversible lithium insertionmetal displacement reactions were suggested as possible alternative anode materials (Poizot et al., 2000):

$$
2 \mathrm{Li}+\mathrm{CoO} \leftrightarrow \mathrm{Li}_{2} \mathrm{O}+\mathrm{Co}
$$


These reactions are not fully reversible and are often characterized by severe hysteresis at high potentials that compromises their use in practical cells. However, such reactions warrant further investigation because it has already been demonstrated that they can be highly reversible, as in high-temperature $\mathrm{Na} / \mathrm{NiCl}_{2}$ (Sudworth, 2001) and $\mathrm{Li} / \mathrm{Fe}_{3} \mathrm{O}_{4}$ (Thackeray et al., 1981, 1984b) cells in which the anion lattice provides a stable framework for the cations during discharge and charge. In particular, the reaction of the $\mathrm{Na} / \mathrm{NiCl}_{2}$ 'Zebra' battery:

$$
2 \mathrm{Na}+\mathrm{NiCl}_{2} \leftrightarrow 2 \mathrm{NaCl}+\mathrm{Ni}
$$

that produces common salt $(\mathrm{NaCl})$ and extruded $\mathrm{Ni}$ on discharge, is $100 \%$ coulombically efficient. The outstanding efficiency of this electrochemical reaction can be attributed to the excellent electronic contact that is maintained between the finely divided $\mathrm{NiCl}_{2}, \mathrm{NaCl}$ and $\mathrm{Ni}$ particles within the cathode matrix at all times during discharge and charge.

4.3 Metals, semimetals and intermetallic compounds

Several metals, such as aluminium and tin, and semimetals such as silicon are attractive anode materials for lithium batteries because they can accommodate a significant quantity of lithium within their structures at potentials less than $1 \mathrm{~V}$ vs. $\mathrm{Li}^{0}$. However, because metals and semimetals have dense, compact structures, lithium insertion is often accompanied by large volumetric changes and by structural transformations. For example, lithium insertion into aluminium necessitates a major structural rearrangement of the $\mathrm{Al}$ atoms during the transition from the face-centeredcubic (fcc) lattice of the parent compound to the fcc lattice of the LiAl product, as shown in Figure 7; the transition results in an increase in the unit cell volume of approximately $100 \%$ (per Al atom). Such severe crystallographic changes result in a break-up of the electrode particles, loss of electronic contact between particles and cycling inefficiency. Significant progress has been made to alleviate these problems by using sputtered thin-film electrodes, notably those containing silicon, and by aligning the deposited electrode matrix so that the volumetric expansion can be accommodated in void spaces between them. However, such techniques are expensive compared to conventional powdered electrode processing techniques.

It is perhaps not surprising that it was Sony Corp., the pioneers and originators of commercial $\mathrm{Li}_{x} \mathrm{C}_{6} /$ $\mathrm{LiCoO}_{2}$ lithium-ion batteries, who were also first to introduce lithium-ion cells with intermetallic anodes into the battery market (Ogisu, 2005). Sony's 'Nexelion' cells, as they are commonly referred to, contain an amorphous $\mathrm{Co}-\mathrm{Sn}-\mathrm{C}$ anode and a lithiummanganese-nickel-cobalt-oxide cathode. During charge and discharge, lithium is cycled in and out of a $\mathrm{Li}_{x} \mathrm{Sn}$ alloy that is embedded within an inactive $\mathrm{Co}-\mathrm{C}$

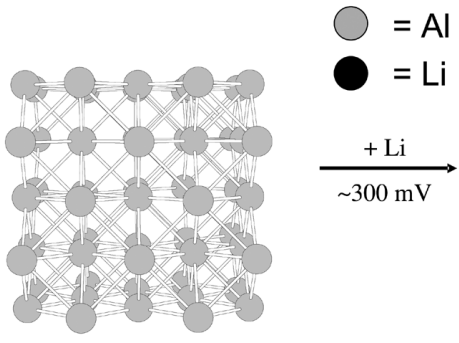

Al, Fm-3m

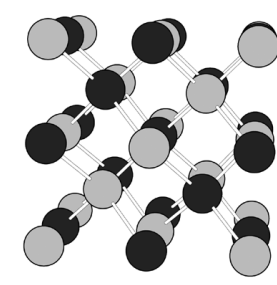

LiAl, Fd-3m
Fig. 7 The fcc-fec transition of Al to LiAl

matrix, following principles described by Mao et al., (1999). Although it has been reported that Nexelion cells can provide $30 \%$ higher capacity than conventional lithium-ion cells, they are targeted for niche applications, such as camcorders. Nevertheless, despite their limited application at present, the introduction of intermetallic anodes in commercial cells bodes well for continued improvements and further exploitation of lithium-ion battery technology.

Over the past few years, several intermetallic compounds have been identified that operate by lithium insertion-metal displacement reactions. In an attempt to find materials that might offer good electrochemical reversibility, an approach has been adopted to seek for systems in which there is a strong structural relationship between the parent compound and its lithiated products. An excellent example is InSb, which has a fcc zinc-blende, diamond-like lattice (Vaughey et al., 2000). Lithium insertion into InSb, which occurs just below $1 \mathrm{~V}$ vs. $\mathrm{Li}^{0}$, is accompanied by the extrusion of In metal to yield $\mathrm{Li}_{3} \mathrm{Sb}$ (Tostmann et al., 2002); the fcc $\mathrm{Sb}$ array, which remains intact throughout the electrochemical reaction, expands by a mere $4 \%$. When the extruded In is taken into consideration, the electrode expands overall by $46.5 \%$. This room temperature reaction, which is analogous to the high-temperature $\mathrm{Na} / \mathrm{NiCl}_{2}$ reaction of 'Zebra' cells, is reversible. However, capacity is lost on cycling $\mathrm{Li} / \mathrm{InSb}$ cells, which is attributed to an exaggerated grain growth of the extruded In crystallites (whiskers) and the loss of electronic contact between the In and $\mathrm{Li}_{3} \mathrm{Sb}$ particles. In principle, however, with an improved electrode design and the suppression of In crystal growth, it should be possible to increase the cycling efficiency and cycling stability of the InSb electrode. Although InSb is an excellent semiconductor and has the structural properties that make it an excellent candidate for further exploitation, its prohibitive cost and the toxicity of Sbcontaining compounds preclude its use in practical lithium-ion cells.

By comparison, the intermetallic compound, $\mathrm{Cu}_{6} \mathrm{Sn}_{5}$ (Kepler et al., 1999) is more attractive as an anode material because 1) it operates below $0.5 \mathrm{~V}$ vs. 


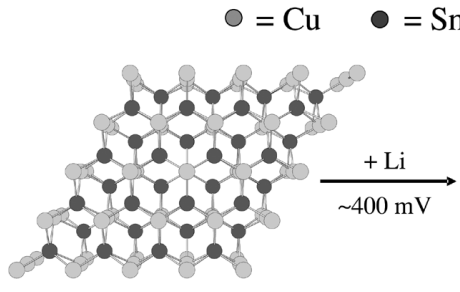

(a)

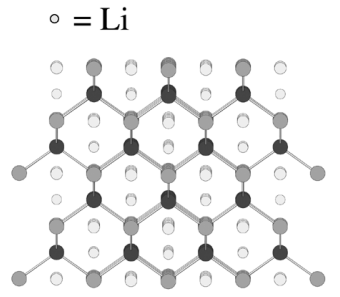

(b)
Fig. 8 The topotactic transformation of $\mathrm{Cu}_{6} \mathrm{Sn}_{5}$ (nickelarsenide-type structure) to $\mathrm{Li}_{2} \mathrm{CuSn}$ (lithiated zincblende-type structure)

$\left.\mathrm{Li}^{0}, 2\right)$ it is relatively inexpensive, and 3) $\mathrm{Cu}$ is the current collector of choice in the anode electrode of conventional lithium-ion batteries. $\mathrm{Cu}_{6} \mathrm{Sn}_{5}$ has a NiAstype structure that transforms topotactically on lithiation to a lithiated zinc-blende-type structure, $\mathrm{Li}_{2} \mathrm{CuSn}$, as shown schematically in Figure 8.

The ideal transformation of the CuSn ('NiAstype') framework in $\mathrm{Cu}_{6} \mathrm{Sn}_{5}$ to the CuSn ('zinc-blende') framework of $\mathrm{Li}_{2} \mathrm{CuSn}$ is accomplished by 1) the introduction of $10 \mathrm{Li}$ atoms, 2) the internal displacement of $50 \%$ of the Sn atoms into interstitial sites, and 3 ) the extrusion of $1 \mathrm{Cu}$ atom per $\mathrm{Cu}_{6} \mathrm{Sn}_{5}$ formula unit (Kepler et al., 1999; Thackeray et al., 2003). Despite the relatively large crystallographic volume change during the $\mathrm{NiAs}$ to lithiated zinc-blende transition (59\%), the process is reversible, although it occurs with some hysteresis. Further lithiation of $\mathrm{Li}_{2} \mathrm{CuSn}$ displaces more copper from the structure to yield, first, a $\mathrm{Li}_{2+x} \mathrm{Cu}_{1-x} \mathrm{Sn}$ solid solution within the range $0<x<1$ and then a binary $\mathrm{Li}_{x} \mathrm{Sn}$ product with $x_{\max } \approx 4$. Highly lithiated $\mathrm{Cu}_{6} \mathrm{Sn}_{5}$ electrodes cycle with lower efficiency than those cycled to an end composition $\mathrm{Li}_{2} \mathrm{CuSn}$ (Kepler et al., 1999); it has recently been demonstrated that substituted $\mathrm{Cu}_{6-x} \mathrm{M}_{x} \mathrm{Sn}_{5}$ electrodes $(\mathrm{M}=\mathrm{Co}, \mathrm{Ni}, \mathrm{Zn}$, $x=1$ ) provide a superior capacity to $\mathrm{Cu}_{6} \mathrm{Sn}_{5}$ (Vaughey et al., 2007). Such lithium insertion/metal extrusion reactions hold promise for further exploitation, particularly if nanosized intermetallic particles can be used to improve the rate capability of intermetallic electrodes and if the problems associated with volumetric expansion and the maintenance of electronic conductivity during electrochemical cycling can be overcome.

\section{Conclusions}

The versatility of lithium-ion battery chemistry and the possibility of designing new electrode and electrolyte materials or improving existing ones will ensure that lithium battery research and development will continue for many more years to come. Paramount to the future success of high energy lithium-ion batteries will rest in the ability to control the chemical and electrochemical reactivity of high capacity electrode materials, particularly those that operate at high or low potentials vs. metallic lithium.

\section{Acknowledgements}

The author wishes to acknowledge all research colleagues, particularly at Argonne National Laboratory, who have contributed to the various sections of work cited in this review paper. Jack Vaughey is thanked, in particular, for providing the structural illustrations. Recent financial support from the Office of Freedom Car and Vehicle Technologies of the U.S. Department of Energy is gratefully acknowledged.

The submitted manuscript has been created by UChicago Argonne, LLC, Operator of Argonne National Laboratory ("Argonne"). Argonne, a U.S. Department of Energy Office of Science laboratory, is operated under Contract No. DE-AC02-06CH11357. The U.S. Government retains for itself, and others acting on its behalf, a paid-up nonexclusive, irrevocable worldwide license in said article to reproduce, prepare derivative works, distribute copies to the public, and perform publicly and display publicly, by or on behalf of the Government.

\section{Literature Cited}

Armstrong, A. R., G. Armstrong, J. Canales and P. G. Bruce; " $\mathrm{TiO}_{2}$ B Nanowires," Angew. Chem. Int. Ed., 43, 2286-2288 (2004)

Armstrong, G., A. R. Armstrong, J. Canales and P. G. Bruce; " $\mathrm{TiO}_{2}(\mathrm{~B})$ Nanotubes as Negative Electrodes for Rechargeable Lithium Batteries," Electrochem. Solid State Lett., 9, A139A143 (2006)

Belharouak, I. and K. Amine; " $\mathrm{Li}_{2} \mathrm{MTi}_{6} \mathrm{O}_{14}(\mathrm{M}=\mathrm{Sr}, \mathrm{Ba})$ : New Anodes for Lithium-Ion Batteries," Electrochem. Commun., 5, 435-438 (2003)

Colbow, K. M., J. R. Dahn and R. R. Haering; "Structure and Electrochemistry of the Spinel Oxides $\mathrm{LiTi}_{2} \mathrm{O}_{4}$ and $\mathrm{Li}_{4} \mathrm{Ti}_{5} \mathrm{O}_{12}$," J. Power Sources, 26, 397-402 (1989)

Dahn, J. R., T. Zheng, Y. H. Liu and J. S. Xue; "Mechanisms for Lithium Insertion in Carbonaceous Materials," Science, 270, 590-593 (1995)

de Picciotto, L. A., K. T. Adendorff, D. C. Liles and M. M. Thackeray; "Structural Characterization of $\mathrm{Li}_{1+x} \mathrm{~V}_{3} \mathrm{O}_{8}$ Insertion Electrodes by Single-Crystal X-Ray Diffraction," Solid State Ionics, 62, 297-307 (1993a)

de Picciotto, L. A., K. T. Adendorff and M. M. Thackeray; Unpublished Data, Council for Scientific and Industrial Research (CSIR), South Africa (1993b)

Ferg, E., R. J. Gummow, A. de Kock and M. M. Thackeray; "Spinel Anodes for Lithium-Ion Batteries," J. Electrochem. Soc., 141, L147-L150 (1994)

Grey, C. P., W.-S. Yoon, J. Reed and G. Ceder; "Electrochemical Activity of Li in the Transition-Metal Sites of O3 $\mathrm{Li}\left[\mathrm{Li}_{(1-2 x) / 3}\right.$ $\left.\mathrm{Mn}_{(2-\mathrm{r}) / 3} \mathrm{Ni}_{x}\right] \mathrm{O}_{2}$, Electrochem. Solid State Lett., 7, A290-A293 (2004)

Gummow, R. J., A. de Kock and M. M. Thackeray; "Improved Capacity Retention of Lithium Manganese Oxide Spinel Cathodes in Lithium Cells," Solid State Ionics, 69, 59-67 (1994)

Hull, S., D. A. Keen, D. S. Sivia and P. Berastegui; "Crystal Structures and Ionic Conductivities of Ternary Derivatives of the Silver and Copper Monohalides-I. Superionic Phases of Stoichiometry MA(4)I(5): $\operatorname{RbAg}_{4} \mathrm{I}_{5}, \mathrm{KAg}_{4} \mathrm{I}_{5}$, and $\mathrm{KCu}_{4} \mathrm{I}_{5}$, , J. Solid State Chem., 165, 363-371 (2002)

Johnson, C. S., D. W. Dees, M. F. Mansuetto, M. M. Thackeray, D. R. Vissers, D. Argyriou, C.-K. Loong and L. Christensen; "Structural and Electrochemical Studies of Alpha Manganese Dioxide $\left(\alpha-\mathrm{MnO}_{2}\right)$," J. Power Sources, 68, 570-577 (1997)

Johnson, C. S., J.-S. Kim, C. Lefief, N. Li, J. T. Vaughey and M. M. Thackeray; "The Significance of the $\mathrm{Li}_{2} \mathrm{MnO}_{3}$ Component in 'Composite' $x \mathrm{Li}_{2} \mathrm{MnO}_{3} \cdot(1-x) \mathrm{LiMn}_{0.5} \mathrm{Ni}_{0.5} \mathrm{O}_{2}$ Electrodes," Electrochem. Commun., 6, 1085-1091 (2004) 
Johnson, C. S., N. Li, J. T. Vaughey, S. A. Hackney and M. M. Thackeray; "Lithium Manganese Oxide Electrodes with LayeredSpinel Composite Structures $x \mathrm{Li}_{2} \mathrm{MnO}_{3} \cdot(1-x) \mathrm{Li}_{1+y} \mathrm{Mn}_{2-y} \mathrm{O}_{4}$ $(0<x<1,0 \leq y \leq 0.33)$ for Lithium Batteries," Electrochem. Commun., 7, 528-536 (2005)

Johnson, C. S., N. Li, C. Lefief and M. M. Thackeray; "Anomalous Capacity and Cycling Stability of $x \mathrm{Li}_{2} \mathrm{MnO}_{3} \cdot(1-x) \mathrm{LiMO}_{2}$ Electrodes $(\mathrm{M}=\mathrm{Mn}, \mathrm{Ni}, \mathrm{Co})$ in Lithium Batteries at $50^{\circ} \mathrm{C}$," Electrochem. Commun., 9, 787-795 (2007)

Kepler, K. D., J. T. Vaughey and M. M. Thackeray; " $\mathrm{Li}_{x} \mathrm{Cu}_{6} \mathrm{Sn}_{5}$ $(0<x<13)$ : An Intermetallic Insertion Electrode for Rechargeable Lithium Batteries," Electrochem. Solid State Lett., 2, 307 309 (1999)

Kim, J.-S., C. S. Johnson and M. M. Thackeray; "Layered $x \mathrm{LiMO}_{2} \cdot(1-x) \mathrm{Li}_{2} \mathrm{MO}_{3}$ Electrodes for Lithium Batteries: A Study of $0.95 \mathrm{LiMn}_{0.5} \mathrm{Ni}_{0.5} \mathrm{O}_{2} \cdot 0.05 \mathrm{Li}_{2} \mathrm{TiO}_{3}$, Electrochem. Commun., 4, 205-209 (2002)

Kim, J.-S., C. S. Johnson, J. T. Vaughey, M. M. Thackeray, S. A Hackney, W. Yoon and C. P. Grey; "Electrochemical and Structural Properties of $x \mathrm{Li}_{2} \mathrm{M}^{\prime} \mathrm{O}_{3} \cdot(1-x) \mathrm{Li}_{x} \mathrm{Mn}_{0.5} \mathrm{Ni}_{0.5} \mathrm{O}_{2}$ Electrodes for Lithium Batteries ( $\left.\mathrm{M}^{\prime}=\mathrm{Ti}, \mathrm{Mn}, \mathrm{Zr} ; 0 \leq x \leq 0.3\right)$," Chem Mater., 16, 1996-2006 (2004)

Linden, D. and T. B. Reddy eds.; Handbook of Batteries, 3rd ed., McGraw-Hill, New York, U.S.A. (2002)

Lu, Z. H., L. Y. Beaulieu, R. A. Donaberger, C. L. Thomas and J. R. Dahn; "Synthesis, Structure and Electrochemical Behavior of $\mathrm{Li}\left[\mathrm{Ni}_{x} \mathrm{Li}_{1 / 3-2 \times / 3} \mathrm{Mn}_{2 / 3-x / 3}\right] \mathrm{O}_{2}$," J. Electrochem. Soc., 149, A778A791 (2002)

Lu, W., I. Belharouak, D. R. Vissers and K. Amine; "In situ Thermal Study of $\mathrm{Li}_{1+x}\left[\mathrm{Ni}_{1 / 3} \mathrm{Co}_{1 / 3} \mathrm{Mn}_{1 / 3}\right]_{1-x} \mathrm{O}_{2}$ Using Isothermal Micro-Calorimetric Techniques," J. Electrochem. Soc., 153, A2147-A2151 (2006)

Mao, O., R. A. Dunlap and J. R. Dahn; "Mechanically Alloyed $\mathrm{Sn}-\mathrm{Fe}(-\mathrm{C})$ Powders as Anode Materials for Li-Ion BatteriesI. The $\mathrm{Sn}_{2} \mathrm{Fe}-\mathrm{C}$ System," J. Electrochem. Soc., 146, 405-413 (1999)

Mizushima, K., P. C. Jones, P. J. Wiseman and J. B. Goodenough; " $\mathrm{Li}_{x} \mathrm{CoO}_{2}(0<x \leq 1)$-A New Cathode Material for Batteries of High-Energy Density," Mater. Res. Bull., 15, 783-789 (1980)

Morcrette, M., P. Rozier, L. Dupont, E. Mugnier, L. Sannier, J. Galy and J. M. Tarascon; "A Reversible Copper Extrusion-Insertion Electrode for Rechargeable Li Batteries," Nat. Mater., 2, 755$761(2003)$

Ogisu, K.; "R\&D Activities and Results for Sony Batteries," Batteries 2005 Conference (PowerPoint Presentation), Paris, France (2005)

Ohzuku, T., M. Kitagawa and T. Hirai; "Electrochemistry of Manganese Dioxide in Lithium Non-Aqueous Cell. 3. X-Ray Diffractional Study on the Reduction of Spinel-Related Manganese Dioxide," J. Electrochem. Soc., 137, 769-775 (1990)

Padhi, A. K., K. S. Nanjundaswamy and J. B. Goodenough; "Phospho-Olivines as Positive Materials for Rechargeable Lithium Batteries," J. Electrochem. Soc., 144, 1188-1194 (1997)

Poizot, P., S. Laruelle, S. Grugeon, L. Dupont and J. M. Tarascon; "Nano-Sized Transition-Metal Oxides as Negative-Electrode
Materials for Lithium-Ion Batteries," Nature, 407, 496-499 (2000)

Ravet, N., Y. Chouinard, J. F. Magnan, S. Besner, M. Gauthier and M. Armand; "Electroactivity of Natural and Synthetic Triphylite," J. Power Sources, 97/98, 503-507 (2001)

Sudworth; J. L.; "Sodium/Nickel Chloride (Zebra) Battery," J. Power Sources, 100, 149-163 (2001)

Thackeray, M. M.; "Manganese Oxides for Lithium Batteries," Prog. Solid State Chem., 25, 1-71 (1997)

Thackeray, M. M. and J. Coetzer; "The Crystal Structure of the Solid Electrolyte $\mathrm{Ag}_{44} \mathrm{I}_{53}\left(\mathrm{C}_{11} \mathrm{H}_{30} \mathrm{~N}_{3}\right)_{3}$," Acta Cryst., B34, 71-75 (1978)

Thackeray, M. M. and J. Coetzer; "A Preliminary Investigation of the Electrochemical Performance of $\alpha-\mathrm{Fe}_{2} \mathrm{O}_{3}$ and $\mathrm{Fe}_{3} \mathrm{O}_{4}$ Cathodes in High Temperature Cells," Mater. Res. Bull., 16, 591597 (1981)

Thackeray, M. M., W. I. F. David, P. G. Bruce and J. B. Goodenough; "Lithium Insertion into Manganese Spinels," Mater. Res. Bull., 18, 461-472 (1983)

Thackeray, M. M., P. J. Johnson, L. A. de Picciotto, P. G. Bruce and J. B. Goodenough; "Electrochemical Extraction of Lithium from $\mathrm{LiMn}_{2} \mathrm{O}_{4}$, "Mater. Res. Bull., 19, 179-187 (1984a)

Thackeray, M. M., W. I. F. David and J. B. Goodenough; "High Temperature Lithiation of $\alpha-\mathrm{Fe}_{2} \mathrm{O}_{3}$ : A Mechanistic Study," J. Solid State Chem., 55, 280-286 (1984b)

Thackeray, M. M., M. H. Rossouw, A. de Kock, A. P. de la Harpe, R. J. Gummow, K. Pearce and D. C. Liles; "The Versatility of $\mathrm{MnO}_{2}$ for Lithium Battery Applications," J. Power Sources, 43/44, 289-300 (1993)

Thackeray, M. M., J. T. Vaughey, C. S. Johnson, A. J. Kropf, R. Benedek, L. M. L. Fransson and K. Edstrom; "Structural Considerations of Intermetallic Electrodes for Lithium Batteries," J. Power Sources, 113, 124-130 (2003)

Thackeray, M. M., C. S. Johnson, J. T. Vaughey, N. Li and S. A. Hackney; "Advances in Manganese-Oxide 'Composite' Electrodes for Lithium-Ion Batteries," J. Mater. Chem., 15, 22572267 (2005)

Thackeray, M. M., S.-H. Kang, C. S. Johnson, J. T. Vaughey, R. Benedek and S. A. Hackney; " $\mathrm{Li}_{2} \mathrm{MO}_{3}$-Stabilized $\mathrm{LiMO}_{2}$ Electrodes for Lithium-Ion Batteries," J. Mater. Chem., 17, 3112-3125 (2007)

Tostmann, H., A. J. Kropf, C. S. Johnson, J. T. Vaughey and M. M. Thackeray; "In situ X-Ray Absorption Studies of Electrochemically Induced Phase Changes in Lithiated InSb," Phys. Rev. B., Condens. Matter, 66, 014106 (2002)

Vaughey, J. T., J. O'Hara and M. M. Thackeray; "Intermetallic Insertion Electrodes with a Zinc-Blende-Type Structure for $\mathrm{Li}$ Batteries: A Study of $\mathrm{Li}_{x} \mathrm{InSb}(0 \leq x \leq 3)$," Electrochem. Solid State Lett., 3, 13-16 (2000)

Vaughey, J. T., J. Owejan and M. M. Thackeray; "Substituted $\mathrm{M}_{x} \mathrm{Cu}_{6-x} \mathrm{Sn}_{5}$ Compounds ( $\mathrm{M}=\mathrm{Fe}, \mathrm{Co}, \mathrm{Ni}, \mathrm{Zn}$ ): Designing MultiComponent Intermetallic Electrodes for Lithium Batteries," Electrochem. Solid State Lett., 10, A220-A224 (2000)

West, K., B. Zachau-Christiansen, S. Skaarup, Y. Saidi, J. Barker, I. I. Olsen, R. Pynenburg and R. Koksbang; "Comparison of $\mathrm{LiV}_{3} \mathrm{O}_{8}$ Cathode Materials Prepared by Different Methods," J. Electrochem. Soc., 143, 820-825 (1996) 